\title{
Asymmetric Fukuyama Cross-Coupling of Racemic Benzylic Zinc Reagents
}

\section{Key words}

Fukuyama crosscoupling

zinc

enantioconvergent transformation

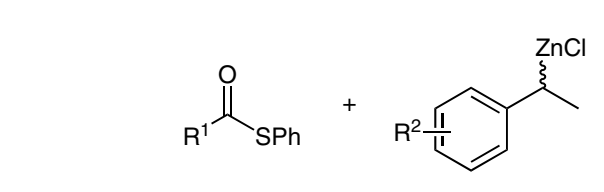

$\mathrm{Pd}(\mathrm{OAc})_{2}(5 \mathrm{~mol} \%)$
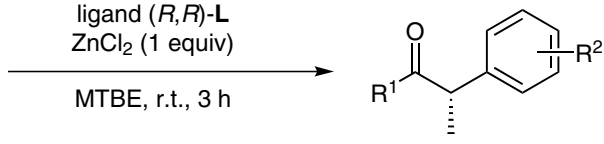

Sy,

$\mathrm{R}^{1}=$ Alk

$\mathrm{R}^{2}=\mathrm{H}, \mathrm{Me}, \mathrm{Cl}, \mathrm{F}, \mathrm{CF}_{3}$

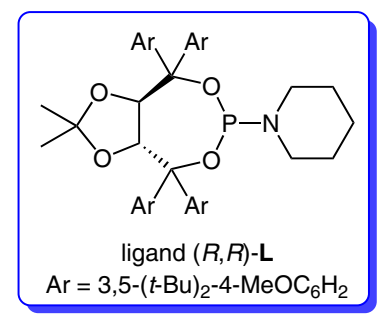

up to $95 \%$ yield er up to $96: 4$

Selected examples:<smiles>C[C@H](C(=O)C1CCCC1)c1ccccc1</smiles>

$90 \%$ yield er $=96: 4$<smiles>C[C@H](C(=O)C1CCN(C(=O)c2ccccc2)CC1)c1ccccc1</smiles>

$82 \%$ yield er $=91.5: 8.5$<smiles>Cc1cc(C)cc([C@@H](C)C(=O)C2CCCC2)c1</smiles>

$78 \%$ yield er $=88.5: 11.5$<smiles>C=C1CCC(C(=O)[C@H](C)c2ccccc2)CC1</smiles>

$81 \%$ yield $\mathrm{er}=88.5: 11.5$<smiles>C[C@H](C(=O)C1CCCC1)c1ccc(C(F)(F)F)cc1</smiles>

$75 \%$ yield $\mathrm{er}=93.5: 6.5$<smiles>COc1ccc(CCC(=O)[C@H](C)c2ccccc2)cc1</smiles>

$95 \%$ yield er $=85: 15$<smiles>CC(C(=O)C1CCC1)c1ccccc1</smiles>

$84 \%$ yield er $=89: 11$<smiles>CC(C)C(=O)[C@H](C)c1ccccc1</smiles>

$77 \%$ yield
Significance: Maulide and co-workers report an enantioconvergent palladium-catalyzed Fukuyama cross-coupling of racemic benzylic zinc reagents with thioesters. A wide range of acyclic $\alpha$-disubstituted carbonyl compounds are afforded in high yields under mild reaction conditions.
Comment: The addition of $\mathrm{ZnCl}_{2}$ significantly improved both the yield and enantioselectivity of the reaction by influencing the Schlenk equilibrium, as well as by accelerating the racemization rate of the secondary organozinc reagents. 